\title{
Decomposition of aquatic macrophytes from Cantá stream (Roraima, Brazil): kinetics approach
}

\author{
Decomposição de macrófitas aquáticas do Igarapé \\ do Cantá (Roraima, Brasil): aspectos cinéticos
}

Marcela Bianchessi da Cunha-Santino ${ }^{1}$, Lucilia Dias Pacobahyba ${ }^{2}$ and Irineu Bianchini Jr. ${ }^{1}$

${ }^{1}$ Departamento de Hidrobiologia, Universidade Federal de São Carlos - UFSCar, Rod. Washington Luiz, Km 235, CEP 13565-905, São Carlos, SP, Brazil e-mail: cunha_santino@ufscar.br, irineu@ufscar.br

${ }^{2}$ Departamento de Biologia, Universidade Federal de Roraima - UFRR, Av. Ene Garcez, 2413, Campus do Paricarana, CEP 69304-000, Boa Vista, RR, Brasil e-mail: lpacobahyba@uol.com.br

\begin{abstract}
Aim: This study aimed at describing and comparing the kinetics of aerobic and anaerobic decomposition of Eleocharis interstincta, Nymphaea sp. and Montrichardia arborescens; Methods: The samples of aquatic macrophytes and water were collected in the Cantá Stream (02 49' $11^{\prime \prime} \mathrm{N}$ and 60 40' 24” W), Cantá, Roraima, Brazil. The plant material was dried and triturated and for each experimental condition (aerobic and anaerobic) mineralization chambers were prepared with plant fragments and stream water. The volume of evolved gases in anaerobic mineralization was monitored during 78 days, while the oxygen consumption was measured for 121 days; Results: The results of aerobic and anaerobic decomposition were fitted to first-order kinetics model. The oxygen consumption varied from $195.36 \mathrm{mg} \mathrm{g}^{-1}$ (DM) for E. interstincta to $629.46 \mathrm{mg} \mathrm{g}^{-1}$ (DM) for Nymphaea sp. The deoxygenation rate derived from mineralization of $M$. arborescens was higher $\left(\mathrm{k}_{\mathrm{D}}: 0.049\right.$ day $\left.^{-1}\right)$, followed by E. interstincta $\left(\mathrm{k}_{\mathrm{D}}: 0.038\right.$ day $\left.^{-1}\right)$ and Nymphaea sp. $\left(k_{\mathrm{D}}: 0.027 \mathrm{day}^{-1}\right)$. For the anaerobic condition the evolution of gases presented two phases: the consumption and formation. According to temporal variations of mineralized carbon, the anaerobic decomposition of $M$. arborescens presents the higher mineralization coefficient $\left(0.0047\right.$ day $\left.^{-1}\right)$; followed by Nymphaea sp. $\left(0.0035 \mathrm{~d}^{-1}\right)$ and E. interstincta $\left(0.0017\right.$ day $\left.^{-1}\right)$; Conclusion: Based on these results we conclude that during the aerobic decomposition of these macrophytes, the Nymphaea sp. was responsible for the higher oxygen demand and $M$. arborescens generated the highest amounts of gases during the anaerobic mineralization. On average, the aerobic decay processes were 11-fold faster than anaerobic. Regarding to the materials fluxes in freshwater ecosystems, low rate of decomposition observed in anaerobic process when comparing to aerobic rates reflect that the sediment represent a very efficient sink of carbon in the organic matter cycling.
\end{abstract}

Keywords: Eleocharis interstincta, Nymphaea sp., Montrichardia arborescens, aerobic and anaerobic process, aquatic macrophytes.

Resumo: Objetivos: Este artigo descreve e compara a cinética de decomposição aeróbia e anaeróbia de Eleocharis interstincta, Nymphaea sp. e Montrichardia arborescens; Métodos: Amostras de água e de macrófitas aquáticas foram coletadas no Igarapé do Cantá ( $02^{\circ} 49^{\prime} 11^{\prime \prime} \mathrm{N}$ e $60^{\circ} 40^{\prime} 24$ ” W), Cantá, Roraima, Brasil. O material foi seco e triturado e para cada condição experimental (aeróbia e anaeróbia), foram preparadas câmaras de mineralizaçấo contendo fragmentos de planta e água do igarapé. O volume de gases na mineralizaçấo anaeróbia foi monitorado durante 78 dias e consumo de oxigênio durante 121 dias; Resultados: Os resultados da decomposição aeróbia e anaeróbia foram ajustados a um modelo cinético de $1^{\text {a }}$ ordem. $O$ consumo de oxigênio variou de $195,36 \mathrm{mg} . \mathrm{g}^{-1}$ (PS) para E. interstincta a $629,46 \mathrm{mg} \mathrm{g}^{-1}$ (PS) para Nymphaea sp. A mineralização de $M$. arborescens apresentou o coeficiente de desoxigenação mais elevado $\left(0,049 \mathrm{dia}^{-1}\right)$, seguida por E. interstincta $\left(0,038 \mathrm{dia}^{-1}\right)$ e Nymphaea sp. $\left(0,027 \mathrm{dia}^{-1}\right) . \mathrm{Na}$ condição anaeróbia, a evolução de gases apresentou duas fases: consumo e formação. De acordo com a variação temporal do carbono mineralizado, a decomposição anaeróbia de $M$. arborescens apresentou o coeficiente de mineralizaçáo mais elevado $\left(0,0047 \mathrm{dia}^{-1}\right)$; seguido por Nymphaea sp. $\left(0,0035 \mathrm{dia}^{-1}\right)$ e de E. interstincta $\left(0,0017 \mathrm{dia}^{-1}\right)$; Conclusáo: Baseado nestes resultados foi possível concluir que durante a decomposição aeróbia dessas 
macrófitas aquáticas, Nymphaea sp. foi responsável pela maior demanda de oxigênio e $M$. arborescens gerou as maiores produçóes de gases durante a mineralização anaeróbia. Em média, o processo aeróbio foi 11 vezes maior que o anaeróbio. Em relação aos fluxos de materiais em ecossistemas de água doce, as baixas taxas de decomposição observadas no processo anaeróbio, quando comparado com as taxas do decaimento aeróbio permite refletir que os sedimentos atuam como um compartimento eficiente de sumidouro de carbono na ciclagem de matéria orgânica.

Palavras-chave: Eleocharis interstincta, Nymphaea sp., Montrichardia arborescens, processo aeróbio e anaeróbio, macrófitas aquáticas.

\section{Introduction}

In freshwater aquatic environments, the detritus (e.g. exudates and tissues) derived from primary producers as aquatic macrophytes is often the main energy source for microorganisms (Boschker et al., 1999) that require pre-synthesized organic matter as a source of carbon and energy (Anesio et al., 2003). Macrophytes are conspicuous components of rivers backwater and littoral zone of lentic environment contributing with large quantities of dissolved (DOC) and particulate organic matter (POM) to the detritus food chain. The hydrosoluble compounds from tissues enter to the DOM pool and degradation process occurs within water column (e.g. through microbial loop). Since POM is deposited in sediments, detritus are degraded initially on the oxic surface before being buried into the anoxic layers where anaerobic decomposition takes place (Bryant et al., 2010).

During decomposition the predominant type of catabolic process are driven by environmental conditions (e.g. redox potential and oxygen availability) that select organisms. Dissolved oxygen availability is one of the most critical ecological forcing function affecting aquatic systems metabolism. Usually, anaerobic metabolism predominates in sediment and aerobic metabolism prevails in water column and in the upper layers of sediments. The oxygen uptake is a function of both dissolved oxygen diffusion to the sediment and oxygen consumption processes (e.g. respiration, oxidation). In general, sediment tends to present greater amounts of recalcitrant organic matter (mainly as POM) when comparing to water column (e.g. labile DOM and low concentration of dissolved carbon ranging from 2 to $10 \mathrm{mg} . \mathrm{L}^{-1}$; Thurman, 1985).

Decomposition of aquatic plants is an important process for the input of carbon and energy and therefore the microbial metabolism associated with dead plant biomass could represent a major route for ecological recovery of organic matter in these environments. Heterotrophic microorganisms use a variety of organic compounds under diverse environmental conditions, extracting energy from these compounds both anaerobically by fermentation and anaerobic respiration and aerobically by aerobic respiration (Madigan et al., 2000). The availability of electrons acceptors will determine the metabolic routes of organic compounds and also the final products of decomposition (Kristensen et al., 2000). Regardless of the oxygen availability in the environment, decomposition processes encompass three distinct mechanisms: leaching, catabolism and fragmentation (Cárcamo et al., 2000). Leaching is an abiotic process by which soluble material from particulate is removed by water (Carpenter, 1980). Catabolism consists in the transformation of complex organic matter into compounds with simple, small molecules and takes place through biochemical reactions (Reddy and DeLaune, 2008). In the fragmentation process, the size of particulate detritus is reduced by macroinvertebrates action within plant fragments (Abelho, 2008). It differs from catabolism because of its physical nature, being generally related to feeding activities - ingestion as well as digestion by decomposing agents.

Considering that decomposition occurs simultaneously both in water column and sediments and the abiotic characteristics of these compartments drive the metabolic route of heterotrophic microorganism, as just outlined, we aimed at describing the kinetics of aerobic and anaerobic decomposition of Eleocharis interstincta, Nymphaea sp. and Montrichardia arborescens, focusing essentially on distinct catabolic microbial process that occurs within to aquatic systems that are essential to organic matter cycling. Our purpose was also to determine the relative speed of aerobic and anaerobic decomposition processes, once degradation rates reflects the residence of organic matter cycling within aquatic compartment. To accomplish this, we conducted two experiments presenting different dissolved oxygen availability, i.e. oxygen uptake assay simulates aerobic decomposition 
in water column and gases production simulates anaerobic decomposition in sediment.

\section{Material and Methods}

\subsection{Plant and water sampling}

Water samples and leaves and stems of Eleocharis interstincta, Montrichardia arborescens and Nymphaea sp. were collected in January/2000 (beginning of flood period) in a macrophyte stand within the Cantá stream in the river backwater zone ( $2^{\circ} 49^{\prime} 11^{\prime \prime} \mathrm{N}$ and $60^{\circ} 40^{\prime} 24$ ' W), State of Roraima, Brazil. The plant samples were washed with tap water to remove periphyton, sediment particles and coarse material (Ogburn et al., 1987). After washing, the plant material was oven-dried $\left(50{ }^{\circ} \mathrm{C}\right)$, grounded $(0.2 \mathrm{~cm}>$ diameter $<0.6 \mathrm{~cm})$ and homogenized. The water samples were filtered (Millipore $1.2 \mu \mathrm{m}$ ) to remove large organisms and coarse detritus.

\subsection{Aerobic assays}

The plant fragments (200 mg. $\left.\mathrm{L}^{-1} \mathrm{DM}\right)$ were placed in duplicate in acid-washed 1-L flasks with stream water samples. The incubations were maintained under aerobic conditions in the dark at $22.5 \pm 2.3^{\circ} \mathrm{C}$. In order to maintain the solutions under aerobic conditions, the incubations were oxygenated in the beginning of experiment during 1 hour, to keep dissolved $\mathrm{O}_{2}$ near saturation. Afterwards, the dissolved oxygen (DO) was measured with an ODmeter (YSI model 58; Yellow Spring Instruments; precision: $\left.0.03 \mathrm{mg} . \mathrm{L}^{-1}\right)$. When concentrations of DO had decreased to approximately $2.0 \mathrm{mg} \mathrm{L}^{-1}$ the solutions were aerated; this procedure was adopted to ensure aerobic condition. The oxygen consumption was estimated during 121 days. To remove the background DO consumption, two blank flasks (with sample of stream water) were also incubated. During the aerobic mineralization, it is usually assumed that the consumed oxygen is proportional to the $\mathrm{CO}_{2}$ formed (e.g. O/C stoichiometry = 2.66; Chapra and Reckhow, 1983). We considered, therefore, that consumption of oxygen was directly related to the oxidation of the organic resource, and that first-order kinetics model can represent this process. Using a non-linear method (Levenberg-Marquardt iterative algorithm; Press et al., 1993) the results were fitted to $1^{\text {st }}$ order kinetics model (Equation 1; Peret and Bianchini Jr., 2004) where the deoxygenation coefficient $\left(\mathrm{k}_{\mathrm{D}}\right)$ and the total amount of consumed oxygen were estimated $\left(\mathrm{OC}_{\max }\right)$.
$\frac{\mathrm{dDO}_{\mathrm{t}}}{\mathrm{dt}}=-\mathrm{k}_{\mathrm{D}} \mathrm{DO}_{\mathrm{t}}$

where: $\mathrm{DO}=$ change per unit time in the amount of dissolved oxygen, mg. $\mathrm{L}^{-1} ; \mathrm{k}_{\mathrm{D}}=$ deoxygenation rate constant $\left(\right.$ day $\left.^{-1}\right)$.

The results of accumulated dissolved oxygen from aerobic decay of macrophytes were analyzed individually using the Kruskal-Wallis test (KW) test followed by Dunn's multiple comparison to detect possible significant differences between treatments $(\mathrm{p}<0.05)$.

\subsection{Anaerobic assays}

For each species of aquatic macrophyte, two chambers were prepared to monitor the formation of gases from anaerobic decomposition processes. These incubations were prepared by the addition of $10.0 \mathrm{~g}(\mathrm{DM})$ of plant fragments in one liter of stream water. The chambers were incubated for 78 days at $28.6 \pm 1.1{ }^{\circ} \mathrm{C}$, in the dark and under anaerobic conditions. In these chambers, the temperature and the volumes of gases were recorded daily, with a mercury thermometer and a low-pressure manometer (Bianchini Jr. et al., 1997), respectively. After each measurement the flasks were depressurized. At the end of experiment the remaining material was fractionated into particulate (POM) and dissolved (DOM) organic matter by filtration (pore size: $0.45 \mu \mathrm{m}$; Millipore). POM samples were oven-dried $\left(45^{\circ} \mathrm{C}\right)$ until constant weight, and their final masses were determined with a gravimetric method (Wetzel and Likens, 1991). The carbon contents of particulate detritus were quantified using a Carlo Erba CHN elemental analyzer (model EA1110), calibrated with external standards (L-cystine, sulphalamine and 2,5-bis[tertbutyl-2-benzoxazolyl]thiophene). The organic carbon concentrations of DOM were measured by $\mathrm{Pt}$-catalyzed non-dispersive combustion and detection in infrared gas analysis (Shimadzu, TOC$5000 \mathrm{~A}$ analyzer). The consumed organic matter (on carbon basis) was calculated by the difference between the initial and final concentrations of dissolved organic carbon and the contents of carbon in the plant fragments. The mineralized carbon (MC) was related to the final value of accumulated volume (obtained from manometric method) by linear regression (volume $(\mathrm{mL})=81.31 \times \mathrm{MC}(\mathrm{g})$; $\left.r^{2}: 0.84\right)$; according to this regression, the kinetics of organic carbon decay were estimated. The organic carbon (dissolved + particulate) decay curves were fitted to $1^{\text {st }}$ order kinetics model (Equation 2; Carvalho et al., 2005) using a non- 
linear method (Levenberg-Marquardt iterative algorithm; Press et al., 1993).

$\frac{\mathrm{dMC}_{\mathrm{t}}}{\mathrm{dt}}=-\mathrm{k}_{\mathrm{M}} \mathrm{MC} \mathrm{C}_{\mathrm{t}}$

where: $\mathrm{MC}=$ change per unit time in the amount of carbon mineralized; $\mathrm{k}_{\mathrm{M}}=$ mineralization rate constant $\left(\right.$ day $\left.^{-1}\right)$.

The results of accumulated gases were analyzed individually using the Kruskal-Wallis test (KW) test followed by Dunn's multiple comparison to detect possible significant differences between treatments $(\mathrm{p}<0.05)$.

\section{Results}

The kinetics of oxygen uptake from the aerobic mineralization of aquatic macrophytes is shown in Figure 1, from which the oxygen uptake deriving from water samples from Cantá Stream (control) was subtracted. $\mathrm{OC}_{\max }$ for the whole 121 days of experiment ranged from $195.36 \mathrm{mg} \cdot \mathrm{g}^{-1}$ (DM) for E. interstincta to $629.46 \mathrm{mg} \cdot \mathrm{g}^{-1}$ (DM) for Nymphaea sp. (Table 1). The mineralization of $M$. arborescens showed the higher constant rate $\left(\mathrm{k}_{\mathrm{D}}: 0.049 \mathrm{day}^{-1}\right)$, followed by mineralization of E. interstincta $\left(\mathrm{k}_{\mathrm{D}}: 0.038\right.$ day $\left.^{-1}\right)$ and Nymphaea sp. $\left(\mathrm{k}_{\mathrm{D}}: 0.027\right.$ day $\left.^{-1}\right)$, as shown in Table 1 .

The KW test showed that oxygen uptake during decomposition of E. interstincta was different statically than $M$. arborescens $(\mathrm{p}<0.001)$ and Nymphaea sp. $(\mathrm{p}<0.001)$.

For all anaerobic incubations, gases were predominantly released in the beginning of the experiments ( 2 to 6 days), with the following maximum daily rates: E. interstincta $(16.2 \mathrm{~mL}$, day: 0.75), Nymphaea sp. (10.0 mL, day: 0.5); $M$. arborescens $11.5 \mathrm{~mL}$; day: 0.5). Then, the consumption processes (negative rates) prevailed (E. interstincta: $6^{\text {th }}$ to $11^{\text {th }}$ day, Nymphaea sp.: $4^{\text {th }}$
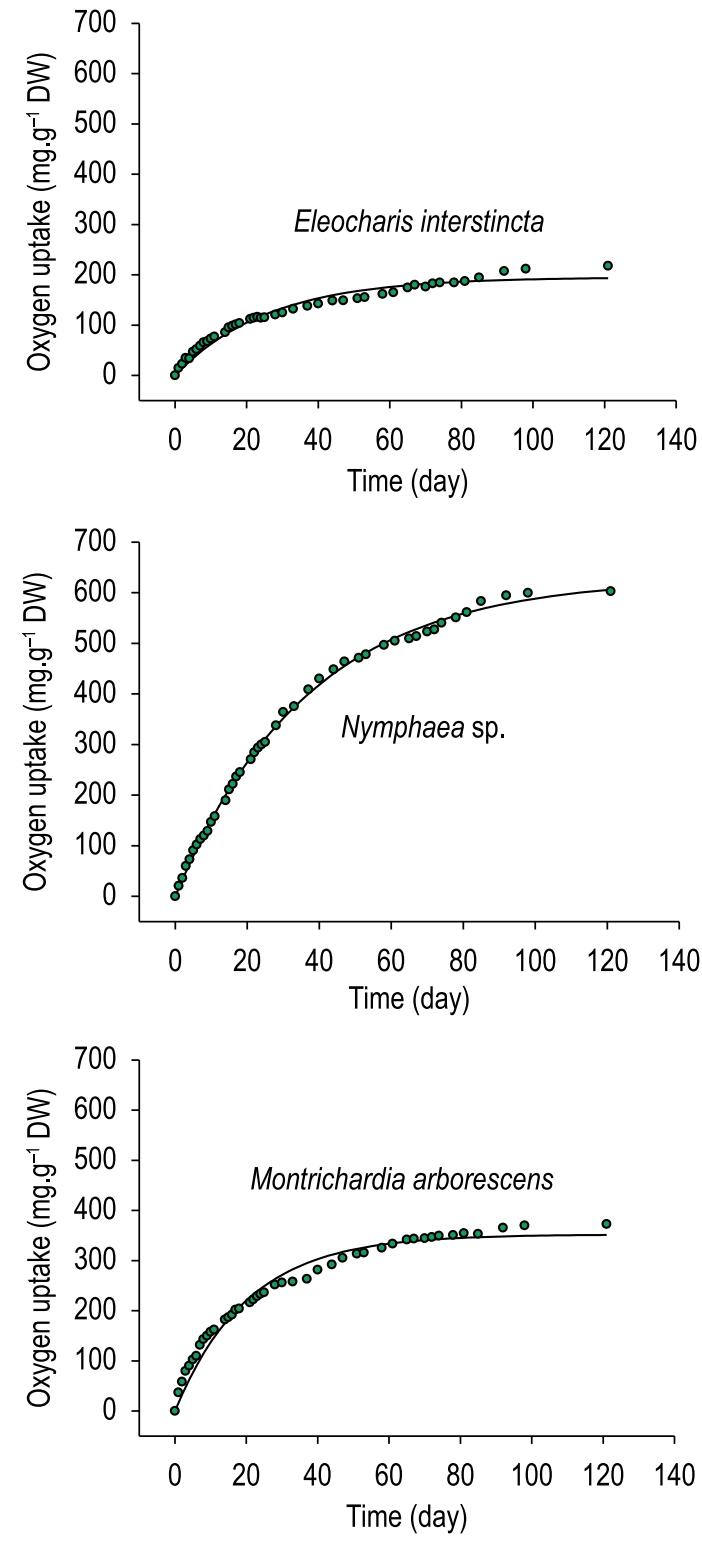

Figure 1. Oxygen uptake kinetics during aerobic decomposition of E. interstincta, Nymphaea sp. and M. arborescens.

Table 1. Carbon budget and kinetics parameters related with anaerobic and aerobic mineralization of aquatic plants.

\begin{tabular}{|c|c|c|c|c|c|c|c|c|}
\hline \multirow{2}{*}{ Anaerobic } & $\mathrm{Ci}$ & $\mathrm{Cf}$ & $\mathrm{MC}$ & Vol & $\mathrm{k}_{\mathrm{M}}$ & error & $t_{1 / 2}$ & \multirow{2}{*}{$r^{2}$} \\
\hline & (mg) & (mg) & $(\mathrm{mg})$ & $(\mathrm{mL})$ & $\left(d^{-1}\right)$ & $\left(d^{-1}\right)$ & (d) & \\
\hline Eleocharis interstincta & 4.42 & 4.03 & 0.39 & 59.70 & 0.0017 & 0.0001 & 398 & 0.82 \\
\hline Nymphaea sp. & 4.70 & 3.73 & 0.97 & 92.40 & 0.0036 & 0.0001 & 195 & 0.94 \\
\hline Montrichardia arborescens & 4.96 & 3.37 & 1.59 & 114.25 & 0.0047 & 0.0001 & 148 & 0.97 \\
\hline \multirow{2}{*}{ Aerobic } & $\mathrm{OC}_{\max }$ & error & $k_{D}$ & error & $t_{1 / 2}$ & \multirow{2}{*}{$r^{2}$} & & \\
\hline & $\left(\mathrm{mg} \cdot \mathrm{g}^{-1}\right)$ & $\left(\mathrm{mg} \cdot \mathrm{g}^{-1}\right)$ & $\left(d^{-1}\right)$ & $\left(d^{-1}\right)$ & (d) & & & \\
\hline Eleocharis interstincta & 195.36 & 4.21 & 0.038 & 0.002 & 18 & 0.97 & & \\
\hline Nymphaea sp. & 629.46 & 4.84 & 0.027 & 0.005 & 25 & 0.99 & & \\
\hline Montrichardia arborescens & 352.17 & 5.47 & 0.049 & 0.003 & 14 & 0.98 & & \\
\hline
\end{tabular}


to $11^{\text {th }}$ day; $M$. arborescens: $2^{\text {nd }}$ to $11^{\text {th }}$ day). In a third stage, as illustrated in Figure 2, the rates of gases formation increased, with these processes being maintained until the end (Figure 2). In this second stage of gases formation, the incubations with $M$. arborescens displayed the highest average rate $\left(2.43 \mathrm{~mL}^{-}\right.$day $\left.^{-1}\right)$ followed by incubation with Nymphaea sp. $\left(1.63 \mathrm{~mL}^{- \text {day }^{-1}}\right)$ and E. interstincta $\left(0.66 \mathrm{~mL}\right.$ day $\left.^{-1}\right)$. After 78 days, the incubations with $M$. arborescens showed the highest gases formation (114.25 mL), while for Nymphaea sp. and E. interstincta, the amount of gases was $92.40 \mathrm{~mL}$ and $59.70 \mathrm{~mL}$, respectively. The consumption of gases was 16.7, 21.3 and $20.1 \mathrm{~mL}$, respectively (Figure 2).

Regardless to anaerobic decomposition, the KW test showed that gases formation were not significant statically among the three species ( $p>0.05$; $\mathrm{KW}=2.454$ ).

According to the changes of MC (Figure 3) the anaerobic decomposition of $M$. arborescens presents the highest mineralization coefficient $\left(0.0047\right.$ day $\left.^{-1}\right)$; followed by decomposition of Nymphaea sp. $\left(0.0035\right.$ day $\left.^{-1}\right)$ and E. interstincta $\left(0.0017 \mathrm{~d}^{-1}\right)$. These
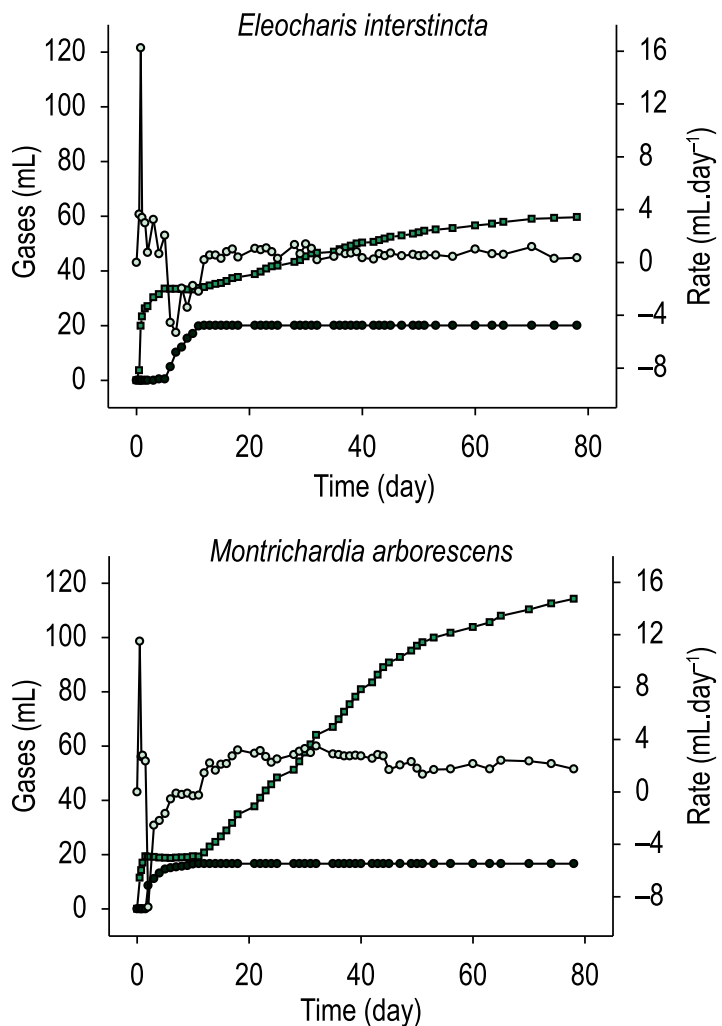

constants rates lead to the following mineralization half-times: $M$. arborescens: 151 days; Nymphaea sp.: 198 days and E. interstincta: 408 days.

\section{Discussion}

The total amount of $\mathrm{OC}_{\max }$, obtained in the dark, is usually employed as a measure of total heterotrophic activity in samples of lake water, soils and sediments (Hantush, 2007; Chomicki and Schiff, 2008; Bond-Lamberty and Thomson, 2010), and it is therefore reasonable to use $\mathrm{OC}_{\max }$ to follow the process of a microbial reaction in aerobic environments (Characklis, 1990). The longterm BOD tests are the experimental procedure to obtain this variable (Cunha-Santino and Bianchini Jr., 2003). Considering the high determination coefficients $\left(\mathrm{r}^{2}\right.$ : from 0.97 to 0.99$)$ obtained from the fittings using the kinetics model (Figure 1) it was possible to verify that the proposed model (Equation 1) was robust to represent the kinetics of oxygen uptake.

From the kinetics point of view, the oxygen consumption was similar to that observed by
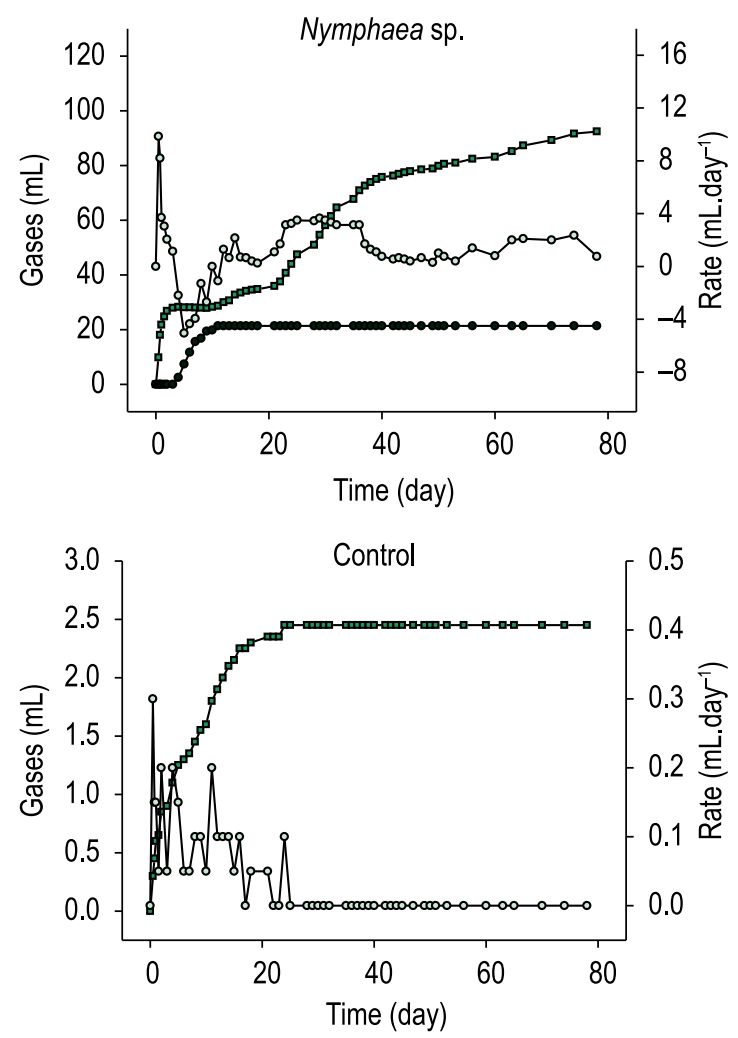

- Consumption •Daily rates - Formation

Figure 2. Gases formation and consumption during anaerobic decomposition of E. interstincta, Nymphaea sp. and M. arborescens. 

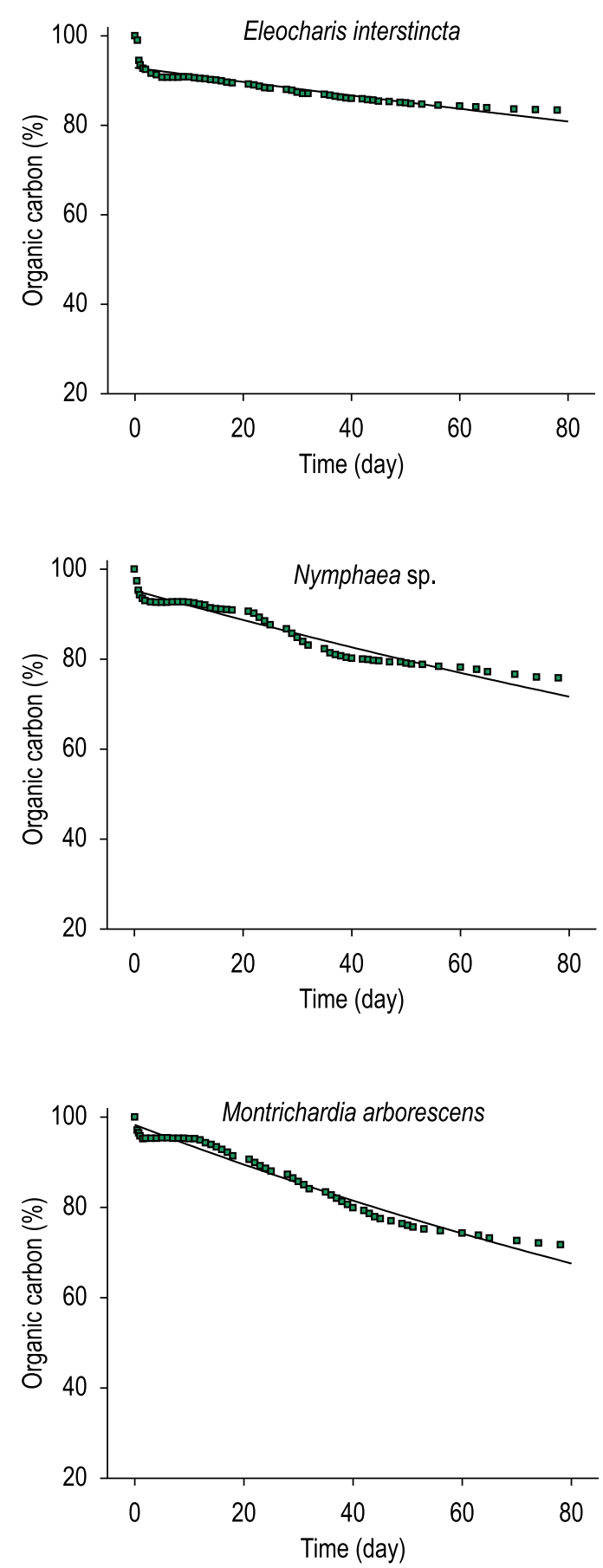

Figure 3. Organic carbon decay during anaerobic mineralization of E. interstincta, Nymphaea sp. and M. arborescens.

Santos et al. (2009). There was a strong increase in oxygen demand in the beginning of the experiment, followed by a decrease in oxidation, tending to stabilization of the process (Figure 1). Considering that aquatic macrophyte detritus is a heterogeneous source of organic matter with labile and refractory compounds, the oxygen uptake was probably related to the labile fractions. On the other hand, the reduction on oxygen uptake was associated with the mineralization of refractory fractions (fibers tissue, e.g. cellulose, lignin and hemicellulose). Decomposition experiments with Eleocharis interstincta showed a labile fraction of $17.3 \%$, to be contrasted with $27.2 \%$ for Nymphaea ampla (Brum and Esteves, 2001); for this specie Bianchini Jr. (1982) observed a labile fraction of $50.2 \%$. The kinetic model for decomposition of Montrichardia arborescens pointed to a labile fraction of 29.3\% (Bianchini Jr. et al., 2002).

Comparing the $\mathrm{OC}_{\max }$ obtained in the present study with similar experiments (Table 2), Nymphaea sp. showed the highest values (629.5 $\left.\mathrm{mg} \mathrm{g}^{-1} \mathrm{DM}\right)$; in fact aerobic mineralization of Nymphaea ampla presented $\mathrm{OC}_{\max }$ values varying from 258.0 to 450.0 mg.g ${ }^{-1}$ DM (Brum et al., 1999; Farjalla et al., 1999). Furthermore, the Egeria najas generated the higher oxygen demand (mg) per g (DM) (699.9 mg.g ${ }^{-1}$ DM; Bianchini Jr. et al., 2008). The lower values of $\mathrm{OC}_{\text {max }}$ obtained in long-term BOD experiments were 32.5 mg. $\mathrm{g}^{-1} \mathrm{DM}$ during decomposition of Typha domingensis and $60.0 \mathrm{mg} \cdot \mathrm{g}^{-1}$ DM for Eleocharis fistulosa (Farjalla et al., 1999). For the decomposition of Eleocharis interstincta we found that $\mathrm{OC}_{\max }$ value was $195.4 \mathrm{mg} . \mathrm{g}^{-1} \mathrm{DM}$; although these values were about 3.3 times that of Eleocharis fistulosa, it was close to other Cyperaceae, such as Oxycaryum cubense: 144.0 and $160.9 \mathrm{mg} . \mathrm{g}$ ${ }^{1}$ DM (Bitar and Bianchini Jr., 2002; Lemos and Bianchini Jr., 1998). On average, considering all experiments listed in Table 2 the mean $\mathrm{OC}_{\max }$ is $278.9 \mathrm{mg} \cdot \mathrm{g}^{-1} \mathrm{DM}$; the $\mathrm{OC}_{\max }$ in the present study was $392.4 \mathrm{mg} \cdot \mathrm{g}^{-1} \mathrm{DM}$. According to Bianchini Jr. (2003), in the aerobic decay of different types of aquatic plants, the $\mathrm{OC}_{\max }$ from mineralization of free-floating and submerged macrophytes was similar (354.4 mg. $\mathrm{g}^{-1} \mathrm{DM}$ ), for emergent aquatic macrophytes this value was $178.8 \mathrm{mg} \cdot \mathrm{g}^{-1} \mathrm{DM}$.

A compilation on oxygen uptake from aquatic plants resources (Bianchini Jr. et al., 2007) showed that, overall, the average of $\mathrm{OC}_{\max }$ from aquatic macrophytes ( $\mathrm{n}=33$ taxons) were $607 \mathrm{mg}^{-\mathrm{g}^{-1}} \mathrm{DM}$ and $\mathrm{k}_{\mathrm{D}}$ was 0.106 day $^{-1}$. Considering the life style of macrophytes: the emergent present an $\mathrm{OC}_{\max }$ $456 \mathrm{mg} \cdot \mathrm{g}^{-1} \mathrm{DM}\left(\mathrm{k}_{\mathrm{D}}=0.121\right.$ day $\left.^{-1}\right)$, for submerged macrophytes these values were $895 \mathrm{mg} \cdot \mathrm{g}^{-1} \mathrm{DM}$ and 0.071 day $^{-1}$. Floating-leaves showed an $\mathrm{OC}_{\max }$ of $753 \mathrm{mg} \cdot \mathrm{g}^{-1} \mathrm{DM}\left(\mathrm{k}_{\mathrm{D}}=0.124 \mathrm{day}^{-1}\right)$. Considering only the macrophytes fibers (ca. cellulose, lignin and hemicelluloses) the $\mathrm{OC}_{\max }$ were $351 \mathrm{mg} \cdot \mathrm{g}^{-1} \mathrm{DM}$ $\left(k_{D}=0.011 \mathrm{day}^{-1}\right)$ and for macrophytes leachates these values were $1253 \mathrm{mg} \cdot \mathrm{g}^{-1} \mathrm{DM}$ and $0.030 \mathrm{day}^{-1}$, respectively. 
Table 2. Parameters derived from oxygen uptake model during aerobic decomposition of aquatic macrophytes. Where: $\mathrm{OC}_{\max }=$ total amount of consumed oxygen and $\mathrm{k}_{\mathrm{D}}=$ the deoxygenation constant rate.

\begin{tabular}{|c|c|c|c|}
\hline Resource & $\mathrm{OC}_{\max }\left(\mathrm{mg} \cdot \mathrm{g}^{-1}\right)$ & $\mathrm{K}_{\mathrm{D}}\left(\right.$ day $\left.^{-1}\right)$ & Reference \\
\hline Cabomba sp. & 342.0 & 0.093 & Bitar, 1995 \\
\hline Cabomba piauhyensis & 339.0 & 0.097 & Cunha and Bianchini Jr., 1998 \\
\hline Cabomba piauhyensis & 384.1 & 0.045 & Bianchini et al., 2008 \\
\hline Cyperus giganteus & 316.7 & 0.025 & Bianchini et al., 2008 \\
\hline Eichhornia azurea & 140.0 & 0.199 & Bitar, 1995 \\
\hline Eichhornia azurea & 279.2 & 0.027 & Bianchini et al., 2008 \\
\hline Eleocharis interstincta & 195.4 & 0.038 & This study \\
\hline Eleocharis fistulosa & 60.0 & 0.040 & Farjalla et al., 1999 \\
\hline Egeria najas & 699.9 & 0.014 & Bianchini et al., 2008 \\
\hline Lemna sp. & 230.0 & 0.230 & Bitar, 1995 \\
\hline Ludwigia inclinata & 393.6 & 0.022 & Romeiro, 2005 \\
\hline Montrichardia arborescens & 235.2 & 0.044 & Cunha-Santino et al., 2004 \\
\hline M. arborescens & 352.2 & 0.049 & This study \\
\hline Myriophyllum aquaticum & 599.9 & 0.018 & Santos et al., 2009 \\
\hline Nymphaea sp & 629.5 & 0.027 & This study \\
\hline Nymphaea ampla & 258.0 & 0.136 & Brum et al.,1999 \\
\hline N. ampla & 450.0 & 0.112 & Farjalla et al., 1999 \\
\hline Oxycaryum cubense & 144.0 & 0.166 & Bitar, 1995 \\
\hline Oxycaryum cubense & 160.9 & 0.011 & Lemos and Bianchini Jr., 1998 \\
\hline Oxycaryum cubense & 274.9 & 0.038 & Bianchini et al., 2008 \\
\hline Potamogeton stenostachys & 377.0 & 0.054 & Brum et al., 1999 \\
\hline P. stenostachys & 360.0 & 0.070 & Farjalla et al., 1999 \\
\hline Salvinia sp. & 185.0 & 0.079 & Bitar, 1995 \\
\hline Salvinia auriculata & 166.3 & 0.041 & Bianchini et al., 2008 \\
\hline Typha domingensis & 139.0 & 0.147 & Brum et al., 1999 \\
\hline T. domingensis & 32.5 & 0.014 & Farjalla et al., 1999 \\
\hline Utricularia breviscapa & 260.0 & 0.045 & Cunha-Santino, 2003 \\
\hline Utricularia breviscapa & 469.7 & 0.023 & Bianchini et al., 2008 \\
\hline Wolffia sp. & 573.5 & 0.079 & Bitar, 1995 \\
\hline Average of this study & 392.4 & 0.038 & \\
\hline Average of all experiments & 312.0 & 0.068 & \\
\hline
\end{tabular}

The results indicated that during aerobic decomposition in the Cantá Stream the dissolved oxygen availability is most affected by Nymphaea sp. $>M$. arborescens $>E$. interstincta. The detritus with higher content of fibers is responsible for the benthic demand of oxygen, since these aquatic macrophytes debris tended to accumulate on the sediment.

The value of deoxygenation coefficient $\left(\mathrm{k}_{\mathrm{D}}\right.$ : 0.027 to 0.049 day $^{-1}$ ) determined for the aerobic mineralization of Nymphaea sp., M. arborescens, $E$. interstincta was lower than the mean value $\left(0.068\right.$ day $\left.^{-1} ; \mathrm{n}=21\right)$ in similar experiments (Table 2).

The accumulated gases generated during the anaerobic decay of Nymphaea sp., $M$. arborescens and $E$. interstincta (Figure 2) result from fermentation and methanogenesis (Bitar, 2003). The time evolution of $\mathrm{CM}$ was associated with the evolved gases. Through its relation with the final mass balance a methodological equivalence of oxidation of the consumed organic matter (on C basis) and the formation of gases could be established. The relation between these results presented a high determination coefficient $\left(r^{2}: 0.84\right)$. From the potential function the daily rates of mineralization of organic matter (CM) could be estimated on a carbon basis (Figure 3).

The anaerobic decomposition of Nymphaea sp., $M$. arborescens and E. interstincta, present two stages. In the first, from $2^{\text {nd }}$ to the $11^{\text {th }}$ day, referred to the consumption processes, there were negative rates, which means that gas consumption by assimilation or solubilization prevailed over gas formation via mineralization. The second stage occurred when the gases probably reached their saturation concentrations and the processes of gas 
formation supplanted the generation of dissolved inorganic compounds (e.g. carbonate ions). This second stage was characterized by intense release of gases with strong increase in daily rates. These higher rates are probably due to the mineralization of labile dissolved compounds, formation of $\mathrm{CH}_{4}$, denitrification, formation of $\mathrm{H}_{2} \mathrm{~S}$ and the adaptation of the heterotrophic community.

Comparing the gas production of Nymphaea sp., $M$. arborescens and $E$. interstincta, in 78 days of decomposition, $M$. arborescens generated the highest amount of gases (1.3 fold for Nymphaea sp. and 1.9 fold for E. interstincta). Studying the decomposition of Eichhornia azurea and Egeria najas, Bitar (2003) observed in 120 days of anaerobic mineralization that the production of gases from E. azurea $(44.9 \mathrm{~mL})$ was smaller than E. najas (199.2 $\mathrm{mL}$ ). According to the author, this difference was probably related to the structural composition of the plants (cellulose contents and labile fraction of carbon). During 213 days of anaerobic decomposition, in vitro assays of Eichhornia azurea in a eutrophic reservoir water produced $94.18 \mathrm{~mL}$ of gases (Cunha-Santino and Bianchini Jr., in press). In the anaerobic decomposition of Cabomba piahuyensis and Oxycaryum cubense, the volume of evolved gases (during 120 days) was, respectively, 213.1 and $36.0 \mathrm{~mL}$ (Cunha and Bianchini Jr., 1998). The aerobic mineralization of $M$. arborescens presented a gaseous yield of $236.9 \mathrm{~mL}$ (127 days). According to Ballester and Santos (2001), in anaerobic environment the gases emissions are mainly $\mathrm{CO}_{2}$, whose origin is organic matter oxidation, denitrification and sulphate reduction; methane arising from methanogenesis; and $\mathrm{N}_{2}$ from denitrification. For an oxbow lake Ballester and Santos (2001) reported maximum rates of gas formation between the $80^{\circ}$ and $90^{\circ}$ days of incubation, with formation of $\mathrm{CO}_{2}$ and $\mathrm{CH}_{4}$ and, in general, prevalence of gas production over consumption. Assays on anaerobic decomposition of Ludwigia sedoides in different temperatures indicated that $\mathrm{CO}_{2}$ formation were produced from the first day of decomposition; in relation to methanogenesis, this gases formation presented different genesis periods: $15^{\text {th }}$ day at $29.9^{\circ} \mathrm{C}$ and $99^{\text {th }}$ at $15.0^{\circ} \mathrm{C}$ (Romeiro and Bianchini Jr., 2008).

The higher mineralization coefficient $\left(\mathrm{k}_{\mathrm{M}}=0.0047 \mathrm{day}^{-1}\right)$ was observed in the anaerobic decomposition of $M$. arborescens, which means that under such conditions these detritus undergo a faster mineralization process than Nymphaea sp. (1.4 times) and E. interstincta (2.8 times). The debris of E. interstincta will probably remain in sediments for long periods; according to a revision made by Little (1979) this genus presented ca. 30\% of DM of crude fibers. The genera Nymphaea presents ca. 16\% of crude fibers (DM) but higher content of phenolic compounds (e.g. Nymphaea alba: $235 \mathrm{mg} \cdot \mathrm{g}^{-1}$ DM; Smolders et al., 2000) and these substances influenced the decomposition process (Kok et al., 1992). M. arborescens presented less phenolic compounds than Nymphaea (ca. 105.8 mg.g $\mathrm{g}^{-1} \mathrm{DM}$; Cunha-Santino et al., 2003).

The results indicate that in the Cantá stream, the cycling of Nymphaea sp., M. arborescens and E. interstincta is more efficient with regard to oxygen uptake (i.e. oxidation of labile organic matter). In this context, according to $\mathrm{k}_{\mathrm{D}}$ and $\mathrm{k}_{\mathrm{M}}$; on average, the aerobic processes were 11 -fold faster than anaerobic ones. The effect of the microbial degradation in the regulation of organic matter content of detritus is related with $\mathrm{k}_{\mathrm{D}}$. It is assumed that the fractions responsible for the high $\mathrm{k}_{\mathrm{D}}$ have reduced periods of half-time, and therefore do not accumulate in the ecosystems. The aerobic decay of labile fraction of aquatic macrophytes can promote great depletion in the dissolved oxygen budget in water column; Nymphaea sp. is the genera that can generate the largest short-term pressures on the dissolved oxygen availability and $M$. arborescens is the aquatic plant detritus that enhanced the gas adduction within this environment. Owning to the time scale of $\mathrm{k}_{\mathrm{M}}$ $\left(\mathrm{t}_{1 / 2}: 151\right.$ to 408 days), the fibrous debris of these plants (POM - refractory fractions), associated with the appropriate values of $\mathrm{pH}$ and oxi-reduction potential, will contributed to the dynamics of gas production and storage of particulate organic matter in sediments of the Cantá Stream. Regarding to the materials fluxes in freshwater ecosystems, low rate of decomposition observed in anaerobic process when comparing to aerobic rates reflect that the sediment represent a very efficient sink in the organic matter cycling.

\section{Acknowledgements}

The authors thank Foundation of Support to Research of the São Paulo State (FAPESP) for the scholarship and financing this assays (Process: 2000/09297-6) and National Counsel of Technological and Scientific Development (CNPq) for the scholarship (Processes: 300959/2004-4 e 150169/2004-3) and also Coordenadoria de Aperfeiçoamento de Pessoal de Nível Superior (CAPES). 


\section{References}

ABELHO, M. 2008. Effects of leaf litter species on macroinvertebrate colonization during decomposition in a Portuguese stream. International Review of Hydrobiology, vol. 93, no. 3, p. 358-371.

ANESIO, AM., ABREU PC. and BIDDANDA BA. 2003. The role of free and attached microorganisms in the decomposition of estuarine macrophyte detritus. Estuarine, Coastal and ShelfScience, vol. 56, p. 197-201.

BALLESTER, MVR. and SANTOS, JE. 2001. Biogenic gases $\left(\mathrm{CH}_{4}, \mathrm{CO}_{2}\right.$ and $\left.\mathrm{O}_{2}\right)$ distribution in a riverine wetland system. Oecologia Brasiliensis, vol. 9, p. 21-31.

BIANCHINI Jr., I. 1982. Contribuição ao estudo da decomposição de plantas aquáticas. São Carlos: Universidade Federal de São Carlos. 178 p. [Dissertação de Mestrado].

BIANCHINI Jr., I. 2003. Modelos de crescimento e decomposição de macrófitas aquáticas. In THOMAZ, SM. and BINI, LM., ed. Ecologia e manejo de macróftas aquáticas. Maringá: Eduem. p. 85-126.

BIANCHINI Jr., I., ANTONIO, RM. and MOURA, LF. 1997. On the manometric method for estimating the anaerobic mineralization in aquatic ecosystems: kinetic and methodological aspects. Revista de Microbiologia, vol. 28, p. 83-90.

BIANCHINI Jr., I., CUNHA-SANTINO, MB. and PERET, AM. 2008. Oxygen demand during mineralization of aquatic macrophytes from an oxbow lagoon. Brazilian Journal of Biology, vol. 68, no. 1, p. 61-67.

BIANCHINI Jr., I., CUNHA-SANTINO, MB., PACOBAHYBA, LD., PANHOTA, RS., PERET, AC., SCIESSERE, L., BITAR, AL., ANTONIO, RM., SANTOS, MG., ROMEIRO, F., NUNES, MF. and SILVA, RH. 2007. Consumos de oxigênio das mineralizaçôes de recursos vegetais aquáticos. In Anais do Simpósio de Ecologia do Programa de Pós-Graduação em Ecologia e Recursos Naturais da UFSCar. São Carlos.

BIANCHINI Jr., I., PACOBAHYBA, LD. and CUNHA-SANTINO, MB. 2002. Aerobic and anaerobic decomposition of Montrichardia arborescens (L.) Schott. Acta Limnologica Brasiliensia, vol. 14, p. 27-34.

BITAR, AL. 1995. Contribuição para o estudo dos processos de mineralização em sistemas aquáticos. São Carlos: Universidade Federal de Sáo Carlos. 47 p. [Monografia].

BITAR, AL. 2003. Mineralização e formação de gases da degradação de Eichhornia azurea Kunth e Egeria najas Planch. São Carlos: Universidade Federal de São Carlos. 118 p. [Tese de Doutorado].
BITAR, AL. and BIANCHINI Jr., I. 2002. Mineralization assays of some organic resources of aquatic systems. Brazilian Journal of Biology, vol. 62, p. 557-564.

BOSCHKER, HTS., BROUWER JFC. and CAPPENBERG, TE. 1999. The contribution of macrophyte-derived organic matter to microbial biomass in salt-marsh sediments: Stable carbon isotope analysis of microbial biomarkers. Limnology and Oceanography, vol. 44, no. 2, p. 309-319.

BRUM, PR. and ESTEVES, FA. 2001. Dry weight loss and chemical changes in the detritus of three tropical aquatic macrophyte species (Eleocharis interstincta, Nymphaea ampla and Potamogeton stenostachys) during decompositon. Acta Limnologica Brasiliensia, vol. 13, p. 61-73.

BRUM, PR., FARJALLA, VF., GONÇALVES Jr., JF., SANTOS, AM., PÔRTO, MT., VIEIRA, EDR., FERREIRA, FM. and BIANCHINI Jr., I. 1999. Aspects of the uptake of dissolved oxygen in Cabiúnas and Imboassica Lagoons (Macaé, RJ). Brazilian Archives of Biology and Technology, vol. 42, p. 433-440.

BRYANT, LD., LORRAI, C., McGINNIS, DF., BRAND, A., WU, A. and LITTLE, JC. 2010. Variable sediment oxygen uptake in response to dynamic forcing. Limnology and Oceanography, vol. 55, no. 2, p. $950-964$.

CÁRCAMO, HA., ABE, TA., PRESCOTT, CE., HOLL, FB. and CHANWAY, C.P. 2000. Influence of millipedes on litter decomposition, $\mathrm{N}$ mineralization and microbial communities in a coastal forest in British Columbia, Canada. Canadian Journal of Forest Research, vol. 30, p. 817-826.

CARPENTER, SR. 1980. Enrichment of Lake Wingra, Wisconsin, by submersed macrophyte decay. Ecology, vol. 61, no. 5, p. 1145-1155.

CARVALHO, P., THOMAZ, SM. and BINI, LM. 2005. Effects of temperature on decomposition of a potential nuisance species: the submerged aquatic macrophyte Egeria najas Planchon (Hydrocharitaceae). Brazilian Journal of Biology, vol. 65, p. 767-777.

CHAPRA, SC. and RECKHOW, KH. 1983. Engineering approaches for lake management - vol. 2: mechanistic modeling. Woburn: Butterworth/Ann Arbor. $492 \mathrm{p}$.

CHARACKLIS, WG. 1990. Kinetics of microbial transformations. In CHARACKLIS, WG. and MARSHALL, KC., ed. Biofilms. New York: John Wiley \& Sons. p. 233-264.

CUNHA, M. B. \& BIANCHINI Jr., I. 1998. Mineralização aeróbia de Cabomba piauhyensis e Scirpus cubensis. Acta Limnologica Brasiliensia, vol. 10, p. 81-91.

CUNHA-SANTINO, MB. and BIANCHINI Jr., I. 2003. Determination of the aeration coefficient 
for long-term BOD experiments. Acta Scientiarum. Biological Science, vol. 25, p. 253-256.

CUNHA-SANTINO, MB. and BIANCHINI Jr., I. Variação temporal da relação estequiométrica $\mathrm{O} / \mathrm{C}$ na decomposição aeróbia de Eichhornia azurea (Sw.) Kunth. in press.

CUNHA-SANTINO, MB., PACOBAHYBA, LD. and BIANCHINI Jr., I. 2003. Changes in the amount of soluble carbohydrates and polyphenols contents during decomposition of Montrichardia arborescens (L.) Schott. Acta Amazonica, vol. 33, p. 469-475.

CUNHA-SANTINO, MB., PACOBAHYBA, LD. and BIANCHINI Jr., I. 2004. O/C stoichiometry from mineralization of Montrichardia arborescens (L.) Schott. Acta Limnologica Brasiliensia, vol. 16, no. 4, p. 351-357.

FARJALLA, VF., MARINHO, CC. and ESTEVES, FA. 1999. Uptake of oxygen in the initial stages of decomposition of aquatic macrophytes and detritus from terrestrial vegetation in a tropical coastal lagoon. Acta Limnologica Brasiliensia, vol. 11, p. 185-193.

KOK, JC., HOF, CHJ., LENSSEN, JPM. and VAN DER VELDE, G. 1992. The influence of $\mathrm{pH}$ on concentrations of proteins and phenolics and resource quality of decomposing floating leaf material of Nymphaea alba L. (Nymphaeaceae) for detritivore Asellu aquaticus (L.). Oecologia, vol. 91, p. 229-234.

KRISTENSEN, E., ANDERSEN, FØ., HOLMBOE, N., HOLMER, M. and THONGTHAM, N. 2000. Carbon and nitrogen mineralization in sediment of the Bangrong mangrove area, Phuket, Thailand. Aquatic Microbial Ecology, vol. 22, p. 199-213.

LEMOS, RMA. and BIANCHINI Jr., I. 1998. Decomposição de Scirpus cubensis Poepp \& Kunth da lagoa do Infernáo (SP): I Efeito do teor de nitrogênio e da quantidade de matéria orgânica. Anais do Seminário Regional de Ecologia, vol. 8, p. 1271-1287.

LITTLE, ECS. 1979. Handbook of utilization of aquatic plants.Rome: FAO. 176 p. FAO Fisheries Technical Paper, no. 187.

MADIGAN, MT., MARTINKO, JM. and PARKER, J. 2000. Brock biology of microorganisms. New York: Prentice Hall. 1088 p.
OGBURN III, RW., BREZONIK, PL. and DELFINO, JJ. 1987. Effect of $\mathrm{pH}$ on phosphorous release during macrophyte (Eleocharis sp.) decomposition. Water Research Bulletin, vol. 23, p. 829-831.

PERET, AM. and BIANCHINI Jr., I. 2004. Stoichiometry of aerobic mineralization (O/C) of aquatic macrophytes leachate from a tropical lagoon (São Paulo - Brazil). Hydrobiologia, vol. 528, p. 167-178.

PRESS, WH., TEUKOLSKY, SA., VETTERLING, WT. and FLANNERY BP. 1993. Numerical recipes in $C$ : the art of scientific computing. New York: Cambridge University Press. 994 p.

REDDY, KR. and DELAUNE, RD. 2008. Biogeochemistry of Wetlands: Science and Applications. Boca Raton: CRC Press. 800 p.

ROMEIRO, F. 2003. Bioensaios de decomposição anaeróbia de macrófitas aquáticas da lagoa do Óleo (Estação Ecológica de Jataí, Luiz Antônio - SP). São Carlos: Universidade Federal de São Carlos. 90 p. [Dissertação de Mestrado].

ROMEIRO, F. and BIANCHINI Jr., I. 2008. Kinetic pathways for anaerobic decomposition of Ludwigia inclinata. Hydrobiologia, vol. 607, no. 1, p. 103-111.

SANTOS, MG., CUNHA-SANTINO, MB. and BIANCHINI Jr., I. 2009. Aerobic decomposition of Myriophyllum aquaticum (Vell.) Verdec. regulated by chemical composition of detritus and temperature. Acta Limnologica Brasiliensia, vol. 21, no. 3., p. 269276.

SMOLDERS, AJP., VERGEER, LHT., VAN DER VELDE, G. and ROELOFS, JGM. 2000. Phenolic contents of submerged, emergent and floating leaves of aquatic and semi-aquatic macrophyte species: why do they differ? Oikos, vol. 91, p. 307-310.

THURMAN, EM. 1985. Organic geochemistry of natural waters. Netherlands: Nijhoff/Junk Po. 497 p.

WETZEL, RG. and LIKENS, GE. 1991. Limnological analyses. New York: Springer-Verlag. 391 p.

Received: 18 May 2010 Accepted: 18 October 2010 